\title{
Composition and biological activities of the aqueous extracts of three scleractinian corals from the Mexican Caribbean: Pseudodiploria strigosa, Porites astreoides and Siderastrea siderea
}

\author{
Alejandro García-Arredondo ${ }^{1 *}$, Alejandra Rojas-Molina', César Ibarra-Alvarado ${ }^{1}$, Fernando Lazcano-Pérez ${ }^{2,3}$, \\ Roberto Arreguín-Espinosa ${ }^{3}$ and Judith Sánchez-Rodríguez ${ }^{4}$
}

\begin{abstract}
Background: Scleractinian corals (stony corals) are the most abundant reef-forming cnidarians found in coral reefs throughout the world. Despite their abundance and ecological importance, information about the diversity of their toxins and their biological activities is very scarce. In this study, the chemical composition and the biological activities of the aqueous extracts of Pseudodiploria strigosa, Porites astreoides and Siderastrea siderea, three scleractinian corals from the Mexican Caribbean, have been assessed for the first time.

Methods: Toxicity of the extracts was assessed in crickets; the presence of cytolysins was detected by the hemolysis assay; the vasoconstrictor activity was determined by the isolated rat aortic ring assay; the nociceptive activity was evaluated by the formalin test. The presence of phospholipases $A_{2}\left(P L A_{2}\right)$, serine proteases, and hyaluronidases was determined by enzymatic methods. Low-molecular-weight fractions were obtained by gel filtration chromatography and ultrafiltration.

Results: Extracts from the three species were toxic to crickets, induced hemolysis in human and rat erythrocytes, produced vasoconstriction on isolated rat aortic rings, and presented phospholipase $A_{2}$ and serine-protease activity. Despite the fact that these corals are not considered to be harmless to humans, the extracts generated significant nociceptive responses. The matrix-assisted laser desorption/ionization time-of-flight (MALDI-TOF) mass spectrometry analysis of the low-molecular-weight fractions revealed the presence of peptides within a mass range of 3000 to $6000 \mathrm{Da}$. These fractions were toxic to crickets and two of them induced a transitory vasoconstrictor effect on isolated rat aortic rings.
\end{abstract}

Conclusion: This study suggests that scleractinian corals produce low-molecular-weight peptides that are lethal to crickets and induce vasoconstriction.

Keywords: Scleractinia, Pseudodiploria strigosa, Porites astreoides, Siderastrea siderea, Toxicity, Hemolysis, Vasoconstriction, Nociceptive response

\footnotetext{
* Correspondence: alejandro.gr@uaq.mx

${ }^{1}$ Departamento de Investigación Química y Farmacológica de Productos

Naturales, Facultad de Química, Universidad Autónoma de Querétaro,

Querétaro 76010, Mexico

Full list of author information is available at the end of the article
} 


\section{Background}

Cnidaria is a phylum containing over 11,000 species of aquatic organisms with radial symmetry [1]; the vast majority occur in marine systems. At the present time, a well-accepted taxonomic classification of this phylum defines two groups. One group, the subphylum Meduzoa, includes the classes Scyphozoa (true jellyfish), Cubozoa (box jellyfish), Staurozoa (stalked jellyfish), Hydrozoa (hydroids), and Polypodiozoa (an endocellular parasite). The other group, the class Anthozoa, includes the subclasses Octocorallia (soft corals and sea pens) and Hexacorallia (sea anemones, zoanthids, and stony corals) [1].

All cnidarians are equipped with specialized stinging cells called nematocytes. Each nematocyte contains a specialized organelle referred to as a nematocyst, which is composed of a capsule filled with venom and an inverted tubule. Following an appropriate stimulation, the tubule is everted and injects the venom into the prey, such that nematocysts are predominantly used for prey capture and defense [2]. It is well-documented that the venomous content of nematocysts comprises mainly proteins and peptides such as enzymes, pore-forming components, and neurotoxins that specifically modulate several types of ion channels [3, 4]. Non-nematocystic toxins have also been found in cnidarian tissues $[5,6]$; most of them are secondary metabolites that are usually released to their surroundings as antipredatory, antimicrobial, allelopathic, and antifouling agents [7].

Cnidarians are considered to be the largest phylum of generally toxic animals [3] and they are undoubtedly a very important source of novel bioactive natural products useful in the generation of new drug lead compounds or pharmacological tools for the study of cell physiology. In this regard, evaluation of the bioactivity of cnidarian extracts provides an overview of the properties of their compounds and their potential pharmacological applications. In addition, these evaluations are important, as they allow one to obtain information about the toxicity and the defensive mechanisms of cnidarians.

Despite the fact that most toxicological studies of cnidarians have focused on the class Anthozoa, the order Scleractinia remains relatively unexplored. Scleractinian corals, also called stony corals, are the most abundant reef-forming cnidarians found in coral reefs throughout the world [8]. In an earlier study, variable toxicity was found in several scleractinian corals from the Great Barrier Reef [9]. In the present study, the chemical composition and the biological activities of the aqueous extracts of three scleractinian corals collected in the Mexican Caribbean - Pseudodiploria strigosa, Porites astreoides, and Siderastrea siderea - were assessed for the first time. The biological activities evaluated were toxicity to crickets, hemolysis, vasoconstriction, and nociceptive activity. Furthermore, enzymatic activities such as phospholipase $\mathrm{A}_{2}\left(\mathrm{PLA}_{2}\right)$, serine protease, and hyaluronidase activity were investigated. Low-molecular-weight fractions were obtained from each extract; some biological activities of these fractions were assessed and also analyzed by matrix-assisted laser-desorption/ionization timeof-flight (MALDI-TOF) mass spectrometry.

\section{Methods}

\section{Laboratory animals}

The animals were permitted free access to standard mouse food pellets and water ad libitum. All experiments were performed in accordance with the Official Standard NOM-062-ZOO-1999 for the production, care, and use of laboratory animals. The care and use of the animals was approved by the Bioethics Committee of the School of Medicine, UAQ.

\section{Materials}

Sodium citrate, citric acid, L-phenylephrine, formalin, $\mathrm{N}$-benzoyl-arginine-p-nitroanilide, trypsin from porcine pancreases, hyaluronic acid sodium salt from Streptococcus equi, hexadecyltrimethylammonium, hyaluronidase from bovine testes type IV-S, and sinapinic acid (>99.0\% purity) were obtained from Sigma (USA). Refined chemicals used for buffer preparations, deionized water, and HPLC grade water were purchased from J.T. Baker (USA). All reagents used in the determination of protein concentration and in electrophoretic analysis were obtained from Bio-Rad (USA).

\section{Specimen collection}

Fragments of corals were collected by scuba diving at depths of 4 to $10 \mathrm{~m}$ from coral reefs along the coast at Puerto Morelos, Quintana Roo state, Mexico, in October 2013. The fragments were kept wet with sea water for their transportation to the laboratory where they were then frozen and stored at $-70{ }^{\circ} \mathrm{C}$. Specimen collection was conducted according to the guidelines of the National Commission of Aquaculture and Fishing, of the Secretariat of Agriculture, Livestock, Rural Development, Fishing, and Feeding of the Mexican Federal Government (permit number PPF/DGOPA-193/13).

\section{Aqueous extract preparation}

Nematocyst discharge of each species was induced by stirring the calcareous fragments in HPLC grade water at $4{ }^{\circ} \mathrm{C}$ for $24 \mathrm{~h}$. The extracts obtained were centrifuged at $3000 \mathrm{rpm}(2060 \times \mathrm{g})$ for $15 \mathrm{~min}$ at $4{ }^{\circ} \mathrm{C}$ and the supernatants were separated; this procedure was repeated twice. The supernatants were freeze-dried and dissolved in HPLC grade water at a concentration of $150 \mathrm{mg} / \mathrm{mL}$ and centrifuged at $3000 \mathrm{rpm}$ for $15 \mathrm{~min}$ at $4{ }^{\circ} \mathrm{C}$. The supernatants obtained were stored at $-70{ }^{\circ} \mathrm{C}$ and used to 
perform the bioassays and other analyses. The protein content of the aqueous extracts was determined by the Bradford assay [10], using a standard curve prepared with lyophilized bovine serum albumin.

\section{Bioassays \\ Toxicity assay}

In order to compare the toxicities of the aqueous extracts, they were assessed in crickets (Acheta domestica) of undetermined sex that weighed $190-210 \mathrm{mg}$ by a method previously described [11]. Briefly, lyophilized extracts were dissolved in insect saline solution $(200 \mathrm{mM}$ $\mathrm{NaCl}, 3.1 \mathrm{mM} \mathrm{KCl}, 5.4 \mathrm{mM} \mathrm{CaCl}_{2}, 4 \mathrm{mM} \mathrm{MgCl}_{2}, 2 \mathrm{mM}$ $\mathrm{NaHCO}_{3}, 0.1 \mathrm{mM} \mathrm{Na} \mathrm{HPO}_{4} ; \mathrm{pH}$ 7.2) and administrated by thoracic injection into crickets (five crickets per dose) at several doses $(1,3.2,10,31.6,100$, and $316 \mu \mathrm{g}$ protein $/ \mathrm{mL}$ ). The injection volume for all crickets, including the controls that received insect saline solution, was $10 \mu \mathrm{L}$. Injections were performed using a $0.3 \mathrm{~mL}$ insulin syringe (BD Ultra-Fine ${ }^{\mathrm{Tw}}$, Terumo Medical Corporation, Elkton, MD, USA). After the injection, the crickets were placed in small plastic containers with food and water ad libitum. Mortality was scored at 24 and $48 \mathrm{~h}$ postinjection. The median lethal dose $\left(\mathrm{LD}_{50}\right)$ values were interpolated by fitting log dose-response curves $(n=3$ / curve) using non-linear regression analysis.

\section{Hemolysis assay}

In order to determine the presence of cytolysins in the extracts, the hemolytic activity in human and rat erythrocytes was monitored according to a previously reported method [12]. Briefly, an aliquot of blood was washed three times with Alsever's solution (120 mM Dglucose, $30 \mathrm{mM}$ sodium citrate, $7 \mathrm{mM} \mathrm{NaCl}$, and $2 \mathrm{mM}$ citric acid; pH 7.4). Washing was done by low-speed centrifugation at $2500 \mathrm{rpm}(1430 \times \mathrm{g})$ for $4 \mathrm{~min}$ at $4{ }^{\circ} \mathrm{C}$. Different concentrations of the aqueous extracts $(0.003$, $0.010,0.032,0.100,0.316,1,3.16,10,31.6$, and $100 \mu \mathrm{g}$ of protein $/ \mathrm{mL}$ ) were combined with the washed erythrocytes $(1 \%)$ and Alsever's solution to comprise a total volume of $1 \mathrm{~mL}$. Next, the samples were incubated at $37^{\circ} \mathrm{C}$ for $30 \mathrm{~min}$. Then the samples were centrifuged at $2500 \mathrm{rpm}(1430 \times \mathrm{g})$ for $4 \mathrm{~min}$.

The $\mathrm{A}_{450}$ of the supernatant containing the hemoglobin released from lysed erythrocytes was measured in a spectrophotometer. Each experiment was normalized with respect to complete hemolysis, which was induced by diluting the erythrocyte sample in deionized water instead of Alsever's solution. One hemolytic unit $\left(\mathrm{HU}_{50}\right)$ was defined as the amount of protein sample required to induce $50 \%$ hemolysis in a $1 \%$ erythrocyte solution at $37{ }^{\circ} \mathrm{C}$ for $30 \mathrm{~min}$. The $\mathrm{HU}_{50}$ values were interpolated by fitting log concentration-response curves $(n=3 /$ curve) using non-linear regression analysis.

\section{Isolated rat aortic ring assay}

The assay was carried out in order to determine whether or not the extracts contain components that produce effects on the cardiovascular system [13]. Briefly, male rats (250-275 g) were sacrificed by decapitation and the descending thoracic aorta was removed and placed in icecold, oxygenated Krebs-Henseleit solution (126.8 mM $\mathrm{NaCl}, 5.9 \mathrm{mM} \mathrm{KCl}, 2.5 \mathrm{mM} \mathrm{CaCl} 2,1.2 \mathrm{mM} \mathrm{MgSO}_{4}$, $1.2 \mathrm{mM} \mathrm{KH}_{2} \mathrm{PO}_{4}, 30 \mathrm{mM} \mathrm{NaHCO}$, and $5 \mathrm{mM} \mathrm{D}$ glucose; $\mathrm{pH}$ 7.4). The aorta was immediately flushed with Krebs-Henseleit solution in order to prevent the formation of intravascular clots; it was dissected free of connective tissue and cut into rings at 4 to $5 \mathrm{~mm}$ intervals. The aortic rings were mounted between stainless steel hooks and suspended in $5 \mathrm{~mL}$ water-jacketed organ baths containing oxygenated $\left(95 \% \mathrm{O}_{2}\right.$ and $\left.5 \% \mathrm{CO}_{2}\right)$ Krebs-Henseleit solution at $37{ }^{\circ} \mathrm{C}$. The tissues were allowed to equilibrate for $60 \mathrm{~min}$ under a resting tension of $1.5 \mathrm{~g}$. During this period, the bathing medium was renewed every $15 \mathrm{~min}$.

After a final adjustment of the passive resting tension to $1.5 \mathrm{~g}$, aortic segments were contracted with $100 \mathrm{mM}$ $\mathrm{KCl}$. Once a stable contractile tone was reached, the bathing medium was renewed to restore a resting tension of $1.5 \mathrm{~g}$. The tissues were then contracted with $1 \mu \mathrm{M}$ L-phenylephrine, the force of contraction was recorded, and this contraction was set as $100 \%$. The bathing medium was changed again to restore the original resting tension, and then the aqueous extracts were added to the organ bath. The isometric tension was measured by a Grass FT03 force-displacement transducer connected to a Grass 7D polygraph. The responses were expressed as a percentage of the initial contraction achieved with phenylephrine. The half maximal effective concentration $\left(E_{50}\right)$ and the maximum effect $\left(E_{\max }\right)$ values were interpolated by fitting log concentration-response curves $(n=3 /$ curve) using non-linear regression analysis.

\section{Formalin test}

Acute neurogenic and chronic inflammatory nociception of the extracts were measured using the rat paw formalin test [14]. For this test, extracts $(40 \mu \mathrm{g}$ protein/paw, dissolved in $50 \mu \mathrm{L}$ of sterile saline solution) were injected subcutaneously into the right dorsal hind paw of male Wistar rats weighing 100-120 g ( $n=3 /$ group). The positive control group received $50 \mu \mathrm{L}$ of $2.5 \%$ formalin, while the negative group received $50 \mu \mathrm{L}$ of saline solution. During the test, each rat was placed in a transparent glass container and nociceptive behavior was quantified by counting the time of licking, flinching, and lifting of the injected hind paw using stop-clocks. Measurements were made in two phases: in the first phase (neurogenic), the mice were evaluated from 0 to $10 \mathrm{~min}$ 
post-injection, and in the second phase (inflammatory) from 10 to $50 \mathrm{~min}$ post-injection. The animals were euthanized immediately at the end of the test. All experiments were video-recorded for backup purposes.

\section{$P L A_{2}$ assay}

The PLA $\mathrm{P}_{2}$ activity of the aqueous extracts was determined using a secretory $\mathrm{PLA}_{2}$ colorimetric assay kit (Cayman Chemical, USA). This assay uses the 1,2-dithio analog of diheptanoyl phosphatidylcholine as substrate. Free thiols generated by $\mathrm{PLA}_{2}$ upon hydrolysis of the thioester bond at the sn-2 position were detected using DTNB [5,5'dithio-bis-(2-nitrobenzoic acid)]. Color changes were monitored by a Benchmark Plus microplate spectrophotometer at $414 \mathrm{~nm}$, sampling every minute for $10 \mathrm{~min}$. Ten microliters $(10 \mu \mathrm{g})$ of bee venom $\mathrm{PLA}_{2}$ control was used as the reference for PLA $\mathrm{PL}_{2}$ activity. PLA $\mathrm{A}_{2}$ activity was expressed in $\mu \mathrm{mol}$ of hydrolyzed phosphatidylcholine per minute per $\mathrm{mg}$ of protein $(n=3)$.

\section{Serine protease assay}

Serine protease activity of the extracts was determined by a method previously described [15]. This assay uses the $\mathrm{N}$-benzoyl-arginine-p-nitroanilide as substrate $(0.01 \mathrm{M}, 10 \mu \mathrm{l})$; the rate of hydrolysis was assayed in $0.1 \mathrm{M}$ Tris- $\mathrm{HCl}, \mathrm{pH}$ 8. The yellow $\mathrm{p}$-nitroanilide generated was monitored by a microplate spectrophotometer at $405 \mathrm{~nm}$, sampling every two minutes for $60 \mathrm{~min}$. Trypsin from porcine pancreas was used as the reference for serine protease activity. Serine protease activity was expressed in units $(\mathrm{U}) / \mathrm{mg}$ of protein $(n=3)$; one unit of activity is equivalent to an absorbance increase of 0.01 per minute.

\section{Hyaluronidase assay}

Hyaluronidase activity was determined according to a turbidimetric method [16]. In short, different concentrations of venoms $(1,2.5,5,7.5,10,15,20$, and $25 \mu \mathrm{g} /$ $\mathrm{mL})$ diluted in $150 \mu \mathrm{L}$ buffer $(0.2 \mathrm{M}$ sodium acetate, $\mathrm{pH}$ 6.0, containing $0.15 \mathrm{M} \mathrm{NaCl}$ ), were incubated with $100 \mu \mathrm{L}$ of substrate $(1 \mathrm{mg}$ of hyaluronic acid sodium salt from Streptococcus equi in $1 \mathrm{~mL}$ of acetate buffer) at $37^{\circ} \mathrm{C}$ for $15 \mathrm{~min}$.

After the incubation period, $1 \mathrm{~mL}$ of hexadecyltrimethylammonium $(2.5 \%)$ in $2 \% \mathrm{NaOH}$ was added to the samples. The resulting turbidity was read at $400 \mathrm{~nm}$ in a microplate spectrophotometer after $30 \mathrm{~min}$ of incubation at room temperature. Hyaluronidase from type IV-S bovine testes was used as the reference for hyaluronidase activity. Enzymatic activity was expressed in turbidity reducing units (TRU)/mg of protein $(n=3)$; one unit of activity corresponded to the amount of enzyme that produced a $50 \%$ reduction in turbidity caused by $200 \mu \mathrm{g}$ of substrate under the conditions described above.

\section{Data analysis and statistics}

Data and statistical analyses were performed in Prism 5.0 (GraphPad Software, Inc., USA), and all results were expressed as means \pm standard error of the mean (S.E.M.), of three replicates. The $\mathrm{LD}_{50}, \mathrm{HU}_{50}$, and $\mathrm{EC}_{50}$ values were interpolated by fitting log dose-response curves using non-linear regression analysis. Multiple comparisons were made by a one-way analysis of variance (ANOVA), followed by a post hoc Tukey's test. In the case of the formalin test, the ANOVA was followed by a Dunnett test. In all cases, statistical significance is indicated by $p<0.05$.

\section{SDS-polyacrylamide gel electrophoresis (SDS-PAGE)}

Electrophoretic analyses of the extracts were performed as previously described under native and reducing conditions [17]. Under native conditions, samples were diluted 1:1 in a sample buffer (Bio-Rad, cat \#161-0737). Samples under reducing conditions were diluted 1:1 in a sample buffer containing $\beta$-mercaptoethanol and heated at $95{ }^{\circ} \mathrm{C}$ for $5 \mathrm{~min}$. Then, $12 \%$ polyacrylamide gels, loaded with $15 \mu \mathrm{g}$ of protein, were electrophoresed at $120 \mathrm{~V}$ for $2 \mathrm{~h}$ at $4{ }^{\circ} \mathrm{C}$, using Tris-Glycine as buffer (25 mM Tris, $192 \mathrm{mM}$ glycine, pH 8.3, Bio-Rad, cat \#161-0734). Protein bands were visualized using Coomassie brilliant blue R-250 staining solution (Bio-Rad, cat \#161-0437), and molecular masses were determined by comparison with a broad-range polypeptide standard (Bio-Rad, cat \#161-0318).

\section{Fractionation of extracts}

For the fractionation, the extracts were passed through a fast performance liquid chromatography column (Sephadex G-50, $1.0 \times 48 \mathrm{~cm}$ ) coupled to an ÄKTA purifier system (UPC 100, GE Healthcare). The samples (500 $\mu \mathrm{g}$ of protein $/ 500 \mu \mathrm{L}$ ) were eluted with $1.6 \mathrm{mM}$ acetic acid at a flow rate of $1 \mathrm{~mL} / \mathrm{min}$. The absorbance was read at $280 \mathrm{~nm}$ and fractions $(10 \mathrm{~mL})$ were collected and pooled according to the peaks observed in the chromatogram. Then, the peaks retained in the column were filtrated with Amicon ${ }^{\circ}$ Ultra centrifugation filters with $10 \mathrm{~K}$ cutoff (Merck Millipore, USA). Spin filtration was executed as recommended by the manufacturer manual supplied with the product. The chosen centrifugation time was $20 \mathrm{~min}$ at $14,000 \times \mathrm{g}$.

\section{Mass spectrometry analysis}

The fractions of low molecular mass were analyzed using matrix-assisted laser desorption/ionization time-of-flight (MALDI-TOF) mass spectrometry. Five microliters of a saturated solution of sinapinic acid was added to $10 \mu \mathrm{g}$ of lyophilized fraction. Then, $1 \mu \mathrm{L}$ of this solution was deposited onto the MALDI plate and allowed to dry at room temperature. The spectrum was recorded in linear positive mode on a mass spectrometer (Microflex Bruker 
Daltonics, Germany) equipped with nitrogen laser $\lambda=$ $377 \mathrm{~nm}$ and $20 \mathrm{kV}$ acceleration voltage.

\section{Microscopic examination of nematocysts}

Samples of soft tissues of the corals were obtained using a $0.3 \mathrm{~mL}$ insulin syringe (BD Ultra-Fine ${ }^{\mathrm{Tm}}$, Terumo Medical Corporation, USA) and were observed directly through light microscopy in order to identify the most abundant types of nematocysts in these corals.

\section{Results}

\section{Aqueous extracts}

The aqueous extracts prepared from the three corals showed similar protein concentrations. $P$. strigosa extract had a protein concentration of $10.8 \mathrm{mg} / \mathrm{g}$ of lyophilized powder; the extract obtained from $P$. astreoides showed a protein concentration of $12.9 \mathrm{mg} / \mathrm{g}$; and $1 \mathrm{~g}$ of lyophilized extract of $S$. siderea contained $10.8 \mathrm{mg}$ of protein.

\section{Bioassays}

The insecticidal activity results showed that all extracts were lethal to crickets with similar potency and their lethality did not increase significantly with time. It is important to mention that the potency of the S. siderea extract appeared to increase with time; however, the ANOVA followed by Tukey's test did not show significant differences. Figure 1 shows the dose-response curves while Table 1 displays the $\mathrm{LD}_{50}$ values. The

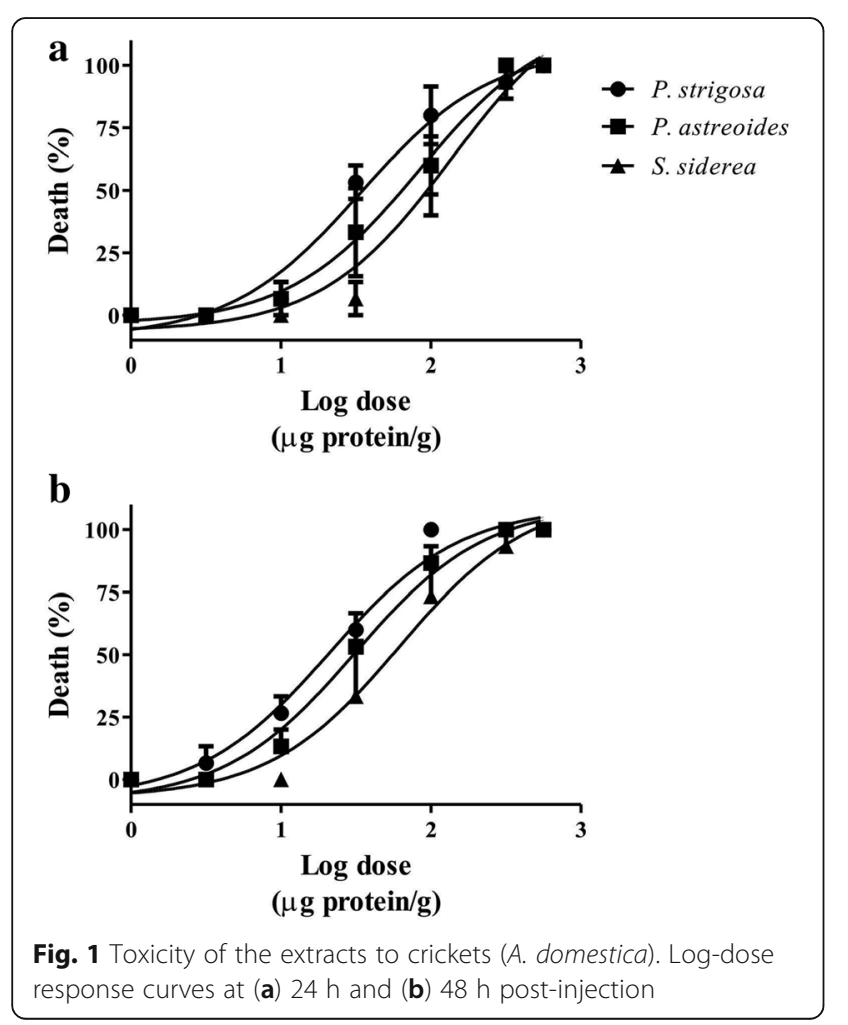

Table 1 Toxicity of the aqueous extracts to crickets expressed as $\mathrm{LD}_{50}(\mu \mathrm{g}$ protein/g)

\begin{tabular}{lcc}
\hline & 24 h post-injection & 48 h post-injection \\
\hline P. strigosa & $33.99 \pm 0.64$ & $21.13 \pm 2.54$ \\
P. astreoides & $37.91 \pm 12.03$ & $33.25 \pm 8.29$ \\
S. siderea & $156.7 \pm 49.07$ & $37.35 \pm 2.18$ \\
\hline
\end{tabular}

extracts did not induce immediate paralysis, but at higher concentrations motility was gradually reduced.

All the extracts induced concentration-dependent hemolytic activity in rat and human erythrocytes (Fig. 2). Table 2 shows $\mathrm{HU}_{50}$ values calculated for the extracts in both types of erythrocytes. The results obtained from the evaluation of rat erythrocytes showed that $P$. strigosa extract was significantly more potent than the others. When the extracts were evaluated in human erythrocytes, it was observed that they induced similar hemolytic activity without significant differences. The $P$. astreoides extract exhibited a low potency in rat erythrocytes, but significantly greater potency in human erythrocytes.

Assessment of the effect of the extracts on the vascular tone of isolated rat aortic rings showed that they induced a vasoconstrictor effect (Fig. 3). Table 3 shows the $\mathrm{EC}_{50}$ and $\mathrm{E}_{\max }$ values calculated for the extracts. It is important to mention that the activity of the extracts was irregular; at concentrations lower than $10 \mu \mathrm{g}$ of

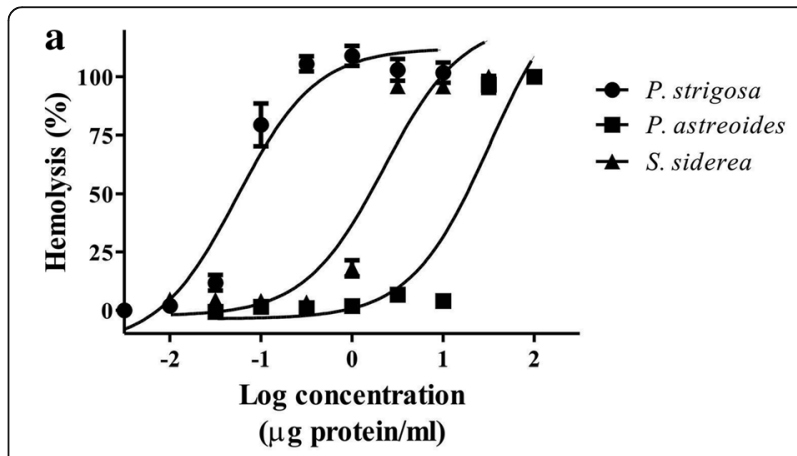

b

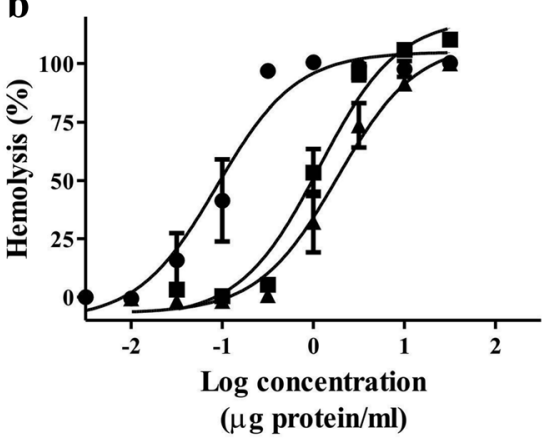

Fig. 2 Log-concentration response curves showing the hemolytic activity of the extracts in (a) rat and (b) human erythrocytes 
Table 2 Hemolytic activity of the aqueous extracts in rat and human erythrocytes expressed as $\mathrm{HU}_{50}(\mu \mathrm{g}$ protein/mL)

\begin{tabular}{lcc}
\hline & Rat erythrocytes & Human erythrocytes \\
\hline P. strigosa & $0.059 \pm 0.015$ & $0.107 \pm 0.042$ \\
P. astreoides & $32.43 \pm 0.955^{*}$ & $3.373 \pm 1.445^{\dagger}$ \\
S. siderea & $2.476 \pm 0.337$ & $3.602 \pm 0.987$
\end{tabular}

${ }^{\dagger}$ Significant difference $(p<0.001)$ compared to the activity in both types of erythrocytes

*Significant difference $(p<0.05)$ compared among the extracts

protein $/ \mathrm{mL}$ the vasoconstriction was sustained, but at a higher concentration (approximately $100 \mu \mathrm{g}$ of protein/ $\mathrm{mL}$ ) the vasoconstriction became transitory. At a concentration of $316 \mu \mathrm{g}$ of protein $/ \mathrm{mL}$, the vasoconstriction induced by the extracts decreased considerably. These irregularities could be due to the presence of mixtures of vasorelaxant and vasoconstrictor components in the extracts. Comparisons between the activities induced by the extracts showed that $P$. strigosa extract was more potent and effective.

Evaluation of nociceptive activity by the formalin test showed that unilateral intraplantar injection of the extracts $(40 \mu \mathrm{g}$ of protein) generated significant nociceptive behavior only during the first phase (Fig. 4). As expected, formalin generated significant biphasic nociceptive behavior.

The results of the enzymatic activity showed that all extracts exhibited $\mathrm{PLA}_{2}$ and serine protease activities, but they did not display hyaluronidase activity. These results are summarized in Table 4.

\section{SDS-PAGE analysis}

Analysis by electrophoresis afforded a preliminary overview of the protein components of the extracts, showing that the extracts contained such components in a broad range (Fig. 5). The profiles of each extract showed particular differences and changes when treated under reducing conditions.

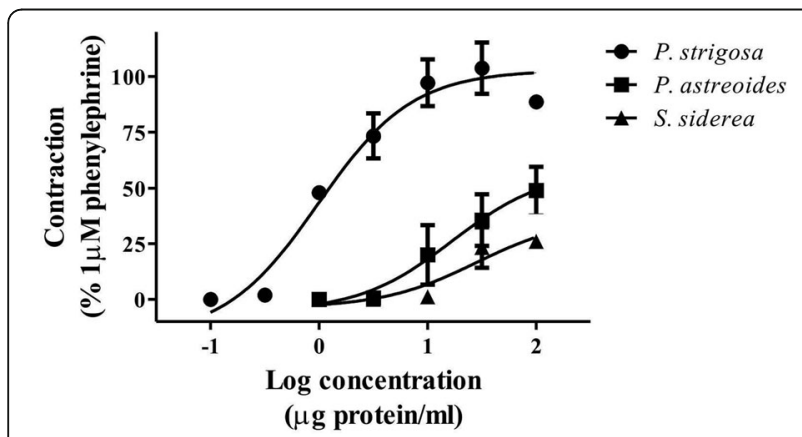

Fig. 3 Log-concentration response curves showing the vasoconstrictor activity of the extracts
Table 3 Vasoconstrictor activity of the aqueous extracts in isolated rat aortic rings

\begin{tabular}{lcc}
\hline & $\mathrm{EC}_{50}(\mu \mathrm{g}$ protein $/ \mathrm{mL})$ & $\mathrm{E}_{\max }$ (\% Response) \\
\hline P. strigosa & $0.983 \pm 0.17^{*}$ & $102.8 \pm 5.63^{*}$ \\
P. astreoides & $16.97 \pm 5.91$ & $58.37 \pm 15.94$ \\
S. siderea & $28.22 \pm 9.17$ & $36.91 \pm 11.00$
\end{tabular}

*Significant difference $(p<0.05)$ compared among the extracts

\section{Composition and biological activities of low-molecular- weight fractions}

Two fractions were separated from each extract using FPLC. The peaks retained in the column (Ps2, $\mathrm{Pa} 2$, and Ss2) were passed through filters with $10 \mathrm{~K}$ cutoff in order to obtain the low-molecular-weight components. The MALDI-TOF mass spectrometry showed that these fractions contain low-molecular-weight peptides, within a mass range of 3000 to $6000 \mathrm{Da}$ (Figs. 6, 7, and 8). These low-molecular-weight fractions were lethal to crickets, $24 \mathrm{~h}$ post-injection, at a dose of $50 \mu \mathrm{g}$ of lyophilized filtrated fraction/g (Fig. 9a). Evaluation of the vasoconstrictor activity of these low-molecular-weight fractions showed that Ps2 and Pa2 induced vasoconstriction at a concentration of $1000 \mu \mathrm{g}$ of lyophilized filtrated fraction/ $\mathrm{mL}$, whereas Ss2 did not display activity (Fig. 9b-c).

\section{Observation of nematocysts}

The microscopic examinations of soft tissues of the corals revealed the presence of two abundant types of nematocysts in P. strigosa, holotrich (Fig. 10a) and p-rhabdoid in two size classes (Fig. 10b-c). The most abundant type of nematocyst observed in $P$. astreoides tissues was holotrich (Fig. 10d), while p-rhabdoid (Fig. 10e) and some holotrich (Fig. 10f) were observed in S. siderea tissues.

\section{Discussion}

In general, cnidarians are considered an important source of bioactive compounds, since this phylum has provided a great number of natural products with diverse structural properties. Many of these compounds could be used for the development of new drugs [3, 4, 18-21] or new pharmacological tools for the study of the basic molecular mechanisms of protein insertion into membranes and protein-lipid interactions [22], and new bioinsecticides [23, 24]. Many of the toxicological studies of cnidarians have focused mainly on electrophysiological analysis and cytolytic properties of anemone toxins (order Actiniaria, class Anthozoa). Other cnidarians have been extensively studied because of their toxicity to humans (classes Cubozoa, Scyphozoa, and Hydrozoa), so it is important to understand their mechanisms of envenomation in order to establish suitable treatments. However, despite their abundance in coral reefs, scleractinian corals have been poorly studied, which is probably 


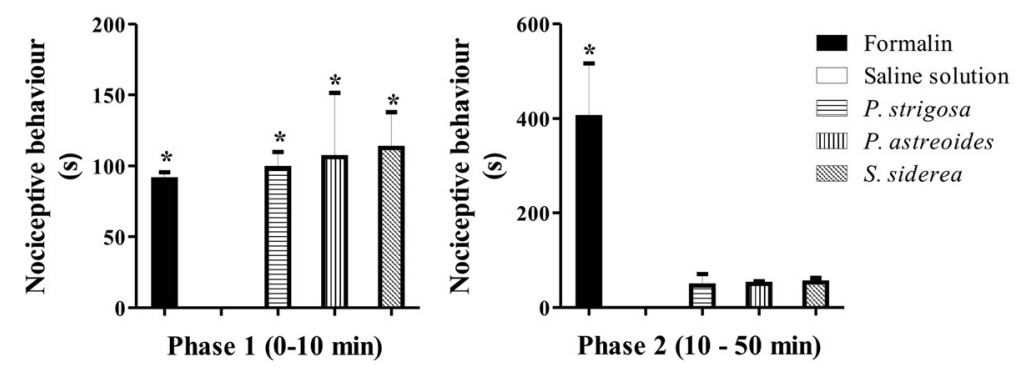

Fig. 4 Formalin test for assessment of the nociceptive activity of the extracts in rats at a dose of $40 \mu \mathrm{g}$ protein/paw. Nociceptive behavior in phase 1 (0-10 min post-injection) and phase 2 (10-50 min post-injection) was scored as the amount of time spent licking, flinching, and lifting. *Significant difference $(p<0.05)$ when compared to the negative group injected with saline solution

due to the difficulty of separating soft tissues from the calcareous skeleton [9] and the fact that they are harmless to humans.

In this study, the bioactive properties of the aqueous extracts of three scleractinian corals collected in the Mexican Caribbean have been assessed for the first time. Considering that cnidarian venoms are composed mainly of peptides and proteins, the parameters of the biological activities of the extracts are expressed a quantity of protein [4]. However, it is possible that some secondary metabolites and other non-peptide components could contribute to the biological activities induced by the extracts. For this reason, the protein yield per gram of lyophilized powder is reported for each extract.

The extracts' toxicity to crickets was determined in order to propose a simple bioassay that would allow an investigator to obtain comparative toxicological data. This assay is widely used to evaluate the toxicological activity of spider and scorpion venom because these animals feed on insects [11]. The natural preys of cnidarians are usually fish and crustaceans; in particular, scleractinian corals feed on small crustaceans and zooplankton [25]. However, the presence of insect-selective toxins in cnidarian venoms, mainly peptides affecting $\mathrm{Na}^{+}$and $\mathrm{K}^{+}$ channels, has been reported and explained from an evolutionary point of view, in which it was proposed that insects are derived from crustacean ancestors [23].

In other studies, we have found that the aqueous extract from Millepora complanata, a reef-forming cnidarian of the class Hydrozoa, was lethal to crickets, with $\mathrm{LD}_{50}$ values of $51.6 \pm 6.59$ and $16.75 \pm 3.69 \mu \mathrm{g}$ protein $/ \mathrm{g}$

Table 4 Enzymatic activity of the aqueous extracts

\begin{tabular}{lccc}
\hline & $\begin{array}{l}\text { PLA } 2 \text { activity } \\
(\mu \mathrm{mol} / \mathrm{min} / \mathrm{mg})\end{array}$ & $\begin{array}{l}\text { Serine protease } \\
\text { activity }(\mathrm{U} / \mathrm{mg})\end{array}$ & $\begin{array}{c}\text { Hyaluronidase } \\
\text { activity }(\mathrm{TRU} / \mathrm{mg})\end{array}$ \\
\hline P. strigosa & $0.03 \pm 0.001$ & $10.27 \pm 1.99$ & - \\
P. astreoides & $0.048 \pm 0.002$ & $11.81 \pm 2.69$ & - \\
S. siderea & $0.043 \pm 0.001$ & $3.95 \pm 0.385$ & - \\
Control & $21.268 \pm 1.965$ & $21.08 \pm 1.857$ & $149.51 \pm 1.405$ \\
\hline
\end{tabular}

at $24 \mathrm{~h}$ and $48 \mathrm{~h}$ post-injection, respectively (unpublished results). M. complanata is a cnidarian that is common in the coral reefs of the Mexican Caribbean and characterized by its capacity to induce local toxic effects in humans that include severe pain, eruptions, and blisters on human skin [26]. In the current study, we found that the extracts from the three scleractinian corals were lethal to crickets, with $\mathrm{LD}_{50}$ values similar to those found for $M$. complanata extract. Moreover, the $\mathrm{LD}_{50}$ values found for these cnidarians are quite similar to those presented by theraphosid spiders [27].

Cytolysins have been widely reported in several cnidarian venoms; they induce hemolysis in erythrocytes of many different species [20]. Most of these toxins have been isolated from anemones and they act through the formation of pores in cellular membranes; a number of reviews have described their structural and functional characteristics [22, 28-31]. Cytolytic activity on sheep erythrocytes has been reported previously from aqueous extracts from 57 scleractinian corals collected

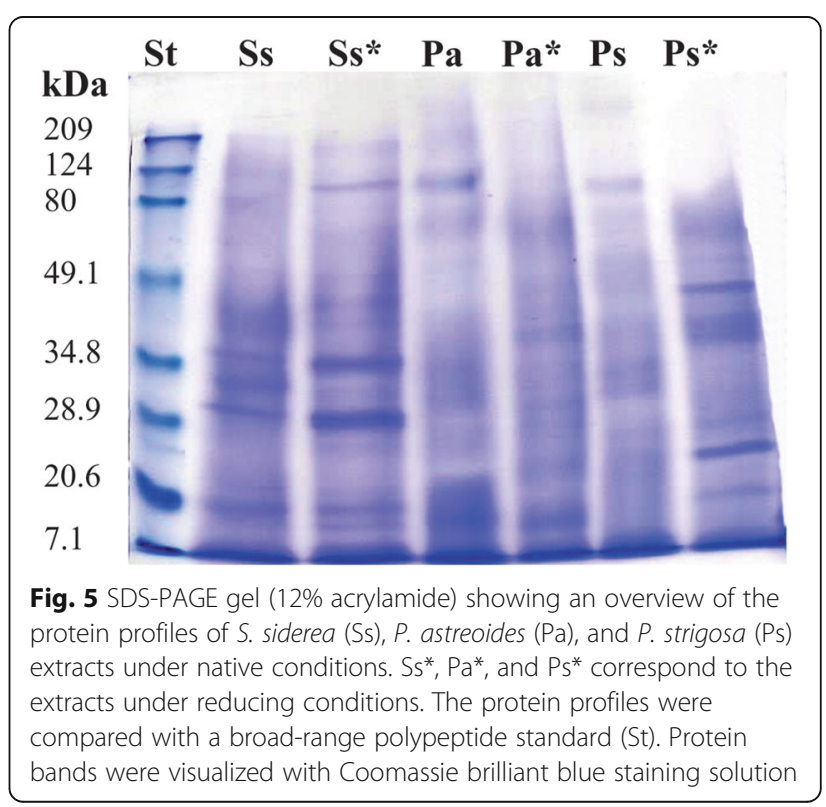



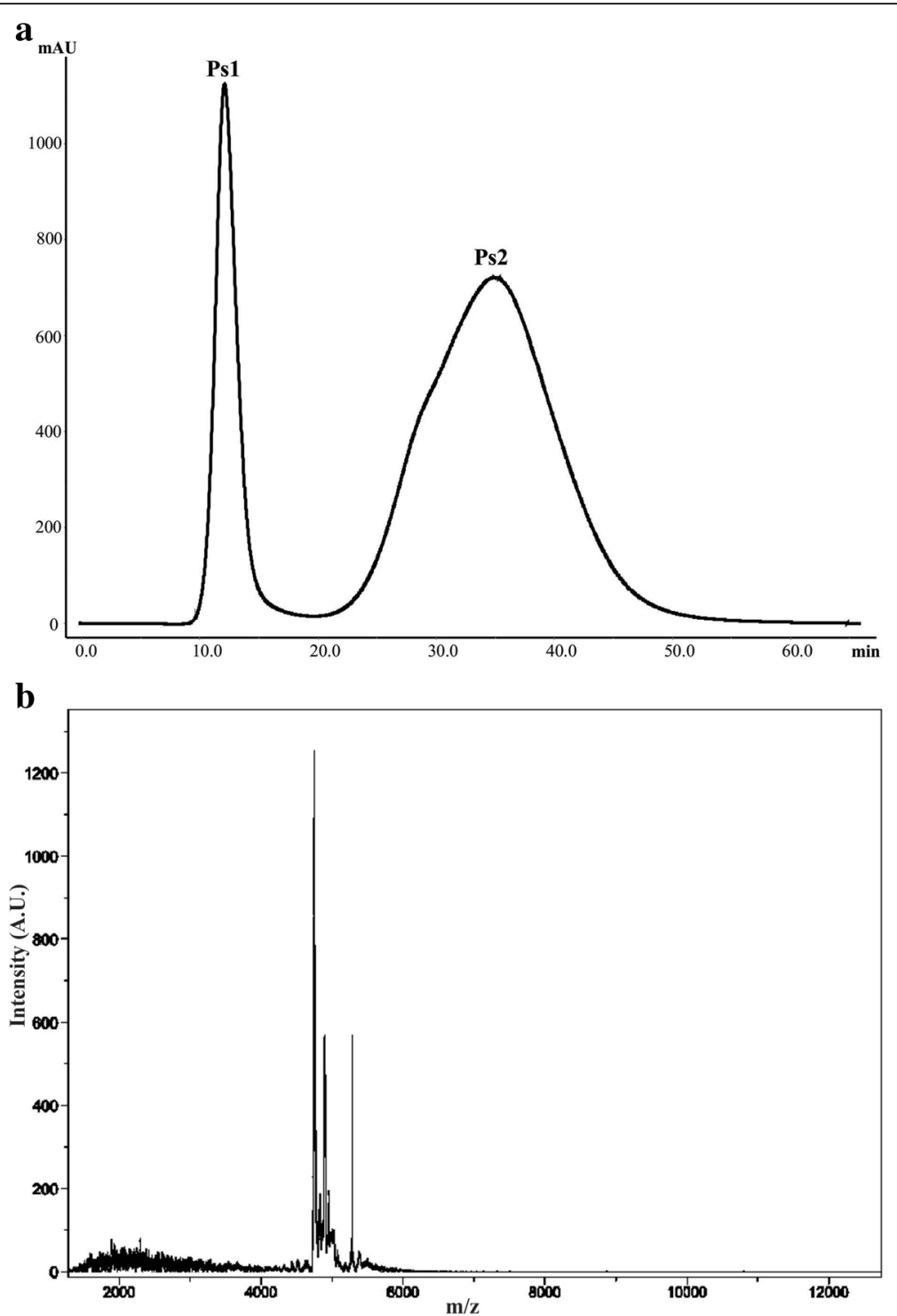

Fig. 6 a P. strigosa extract elution profile obtained by FPLC on a Sephadex G-50 column at $280 \mathrm{~nm}$. The column was equilibrated and eluted with $1.6 \mathrm{mM}$ acetic acid at $1 \mathrm{~mL} / \mathrm{min}$. b MALDI-TOF of the second fraction (Ps2) after filtration with ultra-centrifugation filters with $10 \mathrm{~K}$ cut-off

in the Great Barrier Reef. In that study, it was found that the majority of the extracts were potent lysins, causing more than $90 \%$ hemolysis [9]. The results obtained in this study showed that rat erythrocytes were more sensitive to $P$. strigosa and $S$. siderea extracts, while the $P$. astreoides extract was more potent in human erythrocytes. Upon comparison with our previous study on the hemolytic properties of $M$. complanata aqueous extract [6], we found that $P$. strigosa extract was significantly more potent than $M$. complanata in both types of erythrocytes. These results suggest important differences between the hemolytic mechanisms of these reef-forming cnidarians.

Cnidarian toxins, including cytolysins and neurotoxins, have been studied with regard to their putative activity in the cardiovascular system [32]. It was found that the sea anemone pore-forming toxin EqT III binds to vascular smooth muscle membranes, causing a slight increase in the tension of the isolated porcine coronary artery rings [33]. The venom from the Portuguese man-of-war (Physalia physalis) produces dose-dependent relaxations of norepinephrine-precontracted isolated rabbit arterial rings [34]. The venom of the giant jellyfish Nemopilema nomurai, administrated intravenously in rats, induces dose-dependent hypotension and bradycardia (0.1-2.4 $\mathrm{mg}$ protein $/ \mathrm{kg}$ ); this venom also produces contraction of isolated rat aortic rings [35]. Tentacle extract from the jellyfish Cyanea capillata induces contraction in both endothelium-intact and endothelium-denuded isolated aortic rings [36]. In 

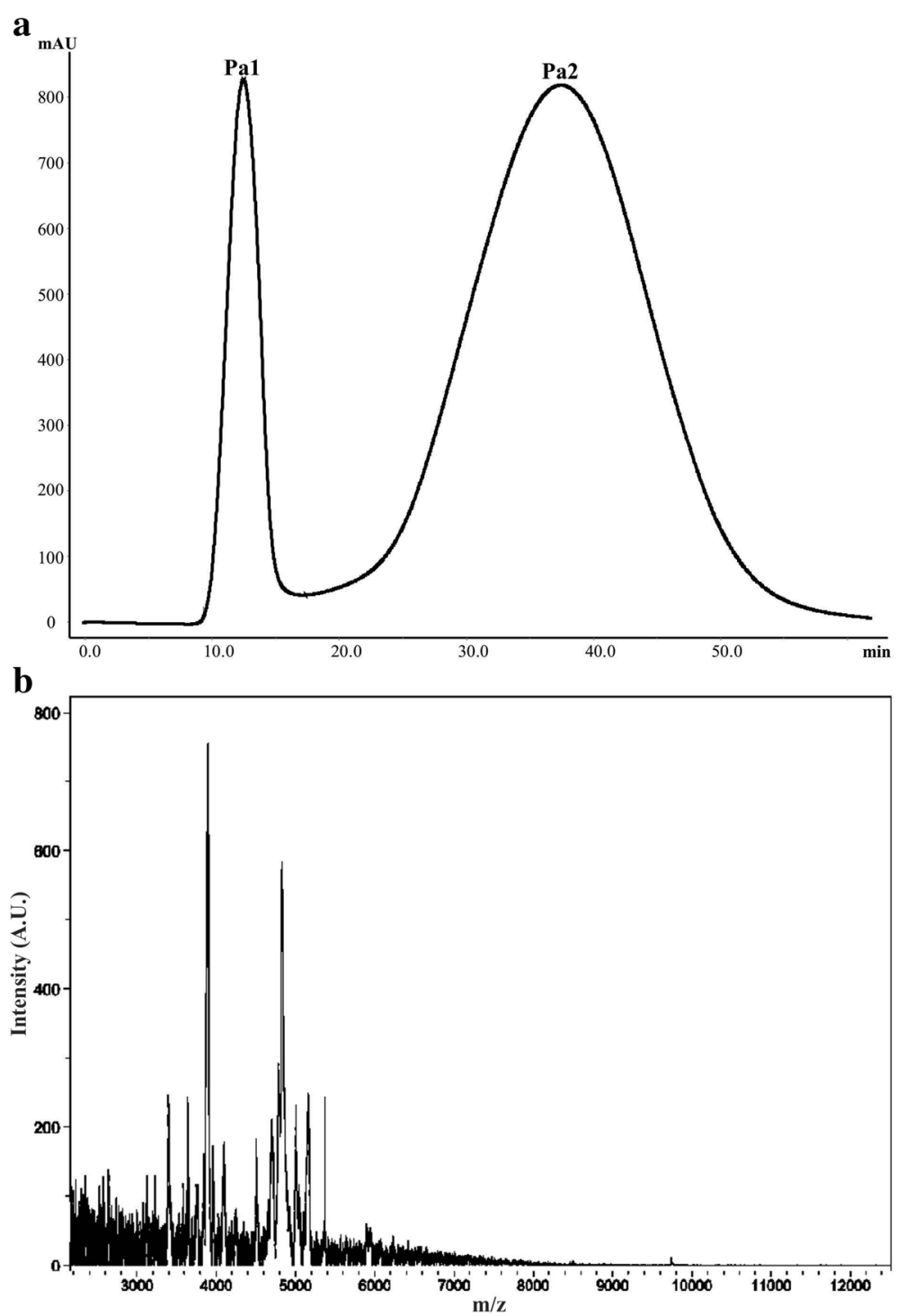

Fig. 7 a $P$. astreoides extract elution profile obtained by FPLC on a Sephadex G-50 column at $280 \mathrm{~nm}$. The column was equilibrated and eluted with $1.6 \mathrm{mM}$ acetic acid at $1 \mathrm{~mL} / \mathrm{min}$. b MALDI-TOF of the second fraction (Pa2) after filtration with ultra-centrifugation filters with $10 \mathrm{~K}$ cut-off

other studies, it was found that aqueous extracts from the calcareous hydrozoans M. alcicornis and M. complanata induce vasoconstriction of isolated rat aortic rings $[37,38]$.

In this study, the three extracts from these scleractinian corals were also found to induce vasoconstriction in isolated rat aortic rings. P. strigosa was the most potent, showing an $\mathrm{EC}_{50}$ value similar to that previously found for $M$. alcicornis and $M$. complanata [38], both of which are considered toxic to humans [26]. The effects of these scleractinian corals on vascular tone were irregular, since at high concentrations a vasodilator effect appeared to predominate, especially with $P$. astreoides and $S$. siderea extracts, suggesting the presence of vasodilator compounds in the extracts.
Human contact with some cnidarian species can result in moderate to extreme pain. The degree of envenomation depends on the composition of the venom and its method of introduction into the human skin [39]. Severe cases of pain are usually caused by contact with jellyfish, the most dangerous of which is Chironex fleckeri [40]. In the present study, evaluation of nociceptive response by the formalin test showed that all three aqueous extracts induced significant nociceptive behavior during the first phase (neurogenic phase). A previous study showed that the transient receptor potential vanilloid channel type 1 (TRPV1), a non-selective cation channel expressed in nociceptive neurons, is a key component in the signaltransduction pathway of pain generated by cnidarian envenomation [41]. However, it is important to mention 

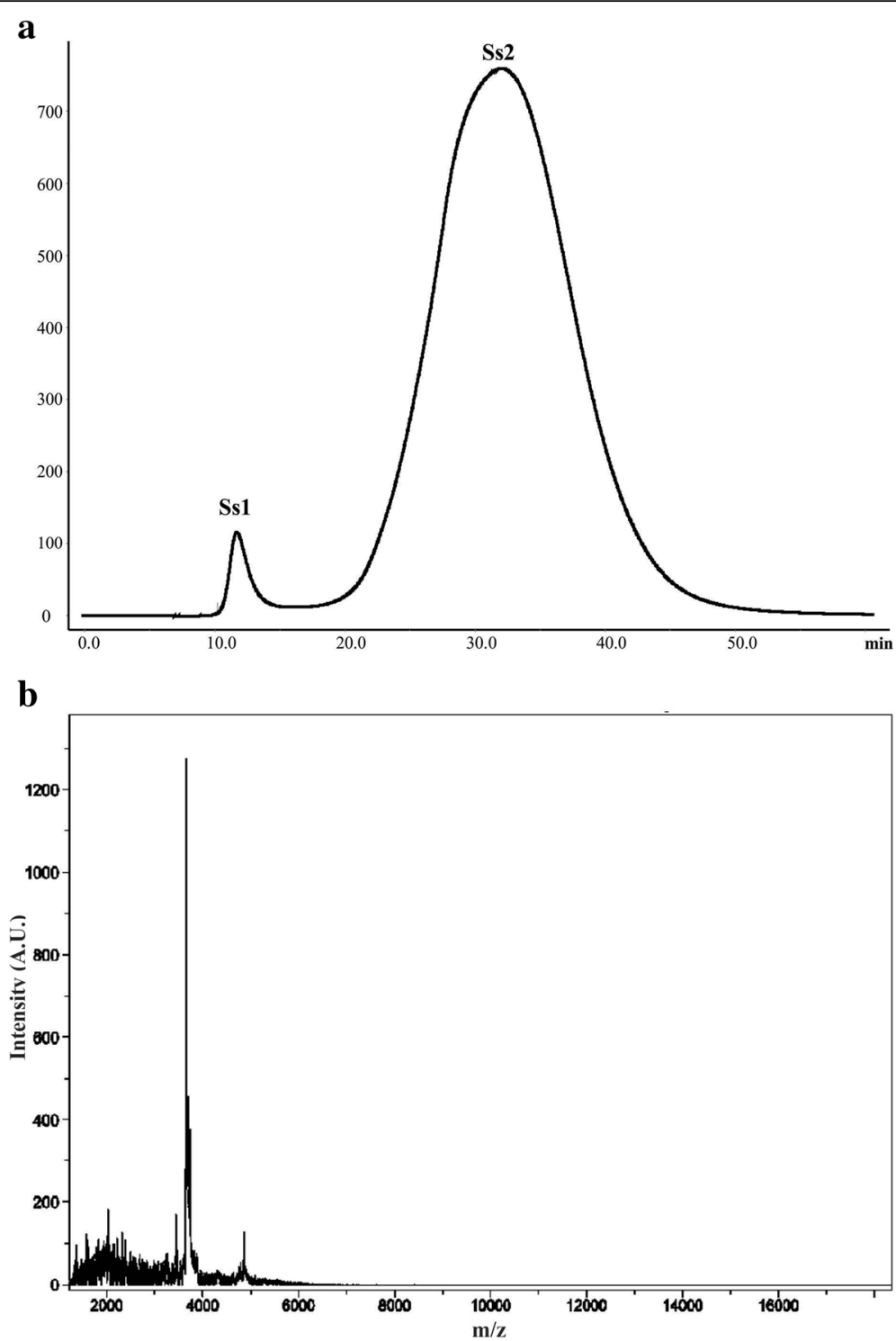

Fig. 8 a S. siderea extract elution profile obtained by FPLC on a Sephadex G-50 column at $280 \mathrm{~nm}$. The column was equilibrated and eluted with $1.6 \mathrm{mM}$ acetic acid at $1 \mathrm{~mL} / \mathrm{min}$. b MALDI-TOF of the second fraction (Ss2) after filtration with ultra-centrifugation filters with $10 \mathrm{~K}$ cut-off

that peptidic TRPV1 inhibitors have also been isolated from sea anemones, suggesting the presence of analgesic compounds in some cnidarian venoms [42, 43].

In the present work, we have evaluated some of the most common enzymatic activities reported for animal venoms. The presence of PLA $\mathrm{P}_{2}$ activity has been widely reported in crude extracts and venoms from several cnidarian species $[20,44]$. These enzymes have also been detected in venoms of many diverse animals and display a broad spectrum of biological activities. Furthermore, $\mathrm{PLA}_{2} \mathrm{~S}$ are considered the major pharmacologically active components of snake venoms [45]. It has been proposed that the presence of $\mathrm{PLA}_{2}$ enzymes in cnidarian venoms plays an important role in defense against predators, and in the immobilization and digestion of prey [20,44]. Moreover, some studies have related $\mathrm{PLA}_{2}$ activity to hemolysis [36, 46].

Serine proteases are other enzymes widely reported in animal venoms that not only have been associated with several physiological functions such as platelet aggregation, fibrinolytic activity, spreading activity of other toxins, but also may induce post-translational modifications of other toxins [47-49]. Hyaluronidases are enzymes widely reported in venoms that are not toxic by themselves, but are known as "spreading factors" because they promote the diffusion of toxins through the tissues of the prey [50]. In a predictive study, potential toxin-encoding genes were identified in 


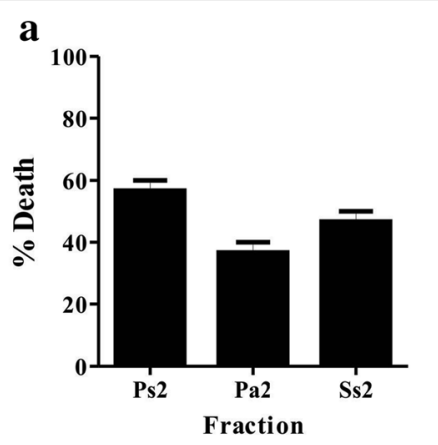

\section{c}
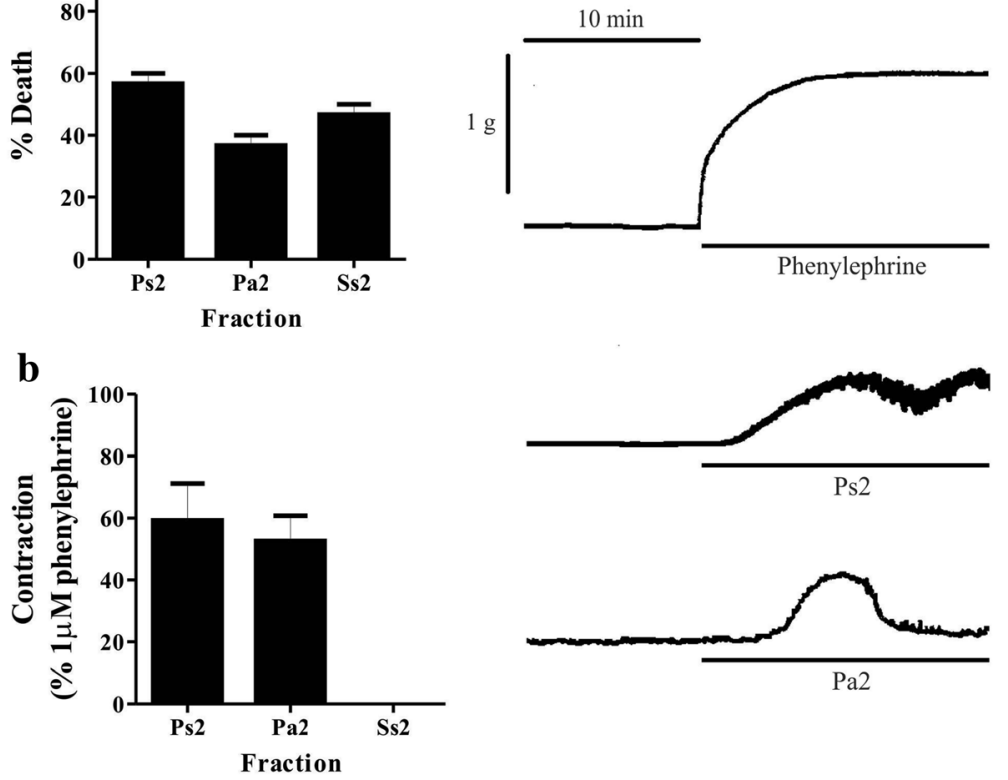

Fig. 9 Biological activities of the low-molecular-weight fractions obtained from the aqueous extracts. a Toxicity to crickets (A. domestica), $24 \mathrm{~h}$ post-injection, at a concentration of $50 \mu \mathrm{g}$ of lyophilized powder/g. $\mathbf{b}$ Vasoconstrictor activity on isolated rat aortic rings at a concentration of $1000 \mu \mathrm{g}$ of lyophilized powder/mL. c Representative recordings showing the vasoconstrictor activity of the fractions $(1000 \mu \mathrm{g} / \mathrm{mL}) \mathrm{compared}$ with the activity induced by phenylephrine $(1 \mu \mathrm{M})$
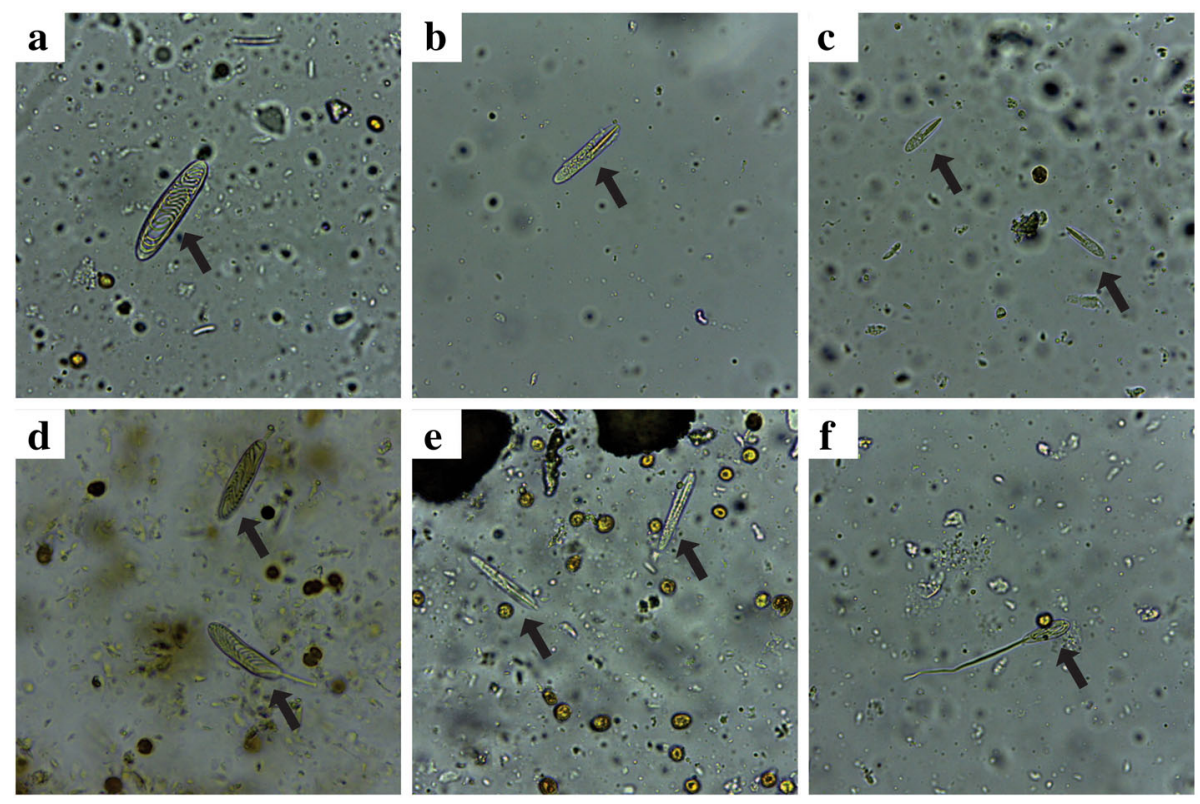

Fig. 10 Light micrographs showing nematocyst found in soft tissues of the corals. a Holotrich of $P$. strigosa, (b) large p-rhabdoid of $P$. strigosa, (c) small p-rhabdoid of $P$. strigosa, (d) holotrich of $P$. astreoides, (e) p-rhabdoid of S. siderea, and (f) holotrich of S. sidereal. Magnification 400X 
the scleractinian coral Acropora digitifera; the same study revealed putative $\mathrm{PLA}_{2}$, serine protease, and hyaluronidase enzymes in that scleractinian coral [51]. Serine proteases have also been detected in the venom of the jellyfish Cyanea capillata by transcriptome analysis [52]. The presence of serine protease and $\mathrm{PLA}_{2}$ in the crude venom from tentacles of the jellyfish Olindias sambaquiensis was experimentally confirmed, showing that the levels of activity of these enzymes were comparable to those observed in venoms of Bothrops snakes [53].

In this study, we experimentally confirm $\mathrm{PLA}_{2}$ presence and serine protease activities in the aqueous extracts of the scleractinian corals $P$. strigosa, $P$. astreoides, and $S$. siderea. These extracts did not display hyaluronidase activity. The levels of $\mathrm{PLA}_{2}$ activity of these scleractinian corals were similar to those previously reported for the hydrozoans $M$. complanata and M. alcicornis [38], whereas the serine-protease activity levels were similar to those observed in jellyfish and snakes [53]. These results suggest that $\mathrm{PLA}_{2}$ and serine proteases play an important role in the toxicity of the scleractinian corals.

Analysis by electrophoresis revealed that the extracts contain proteinaceous components with a wide range of molecular weights and some differences in their compositions. The profiles of the extracts changed under reducing conditions, suggesting the presence of oligomeric proteins. Based on studies of other cnidarians, enzymes correspond to masses between 25 and $50 \mathrm{kDa}[28,53]$, whereas cytolysins are found mainly in the region of $20 \mathrm{kDa}$ [28]. Several reports have shown than cnidarian venoms contain an important mixture of peptides with low molecular weights, mostly between 3 and $7 \mathrm{kDa}$, that act on voltage-gated sodium and potassium channels $[29,54]$, the presence of these neurotoxins in the cnidarian venoms is important for paralyzing their prey.

In fact, all anemone species tested have been found to contain toxins that are lethal or paralytic to crabs [55]. Other low-molecular-weight peptides found in anemones affect channels implicated in pain, such as TRPV1 and acid sensing ion channels [54]. Moreover, lowmolecular-weight cytolytic toxins also have been found in cnidarians; two peptides with molecular masses of 5.1 and $6.1 \mathrm{kDa}$ were isolated from the sea anemone Radianthus macrodactylus [56]. Analysis by MALDITOF mass spectrometry of the low-molecular-weight fractions obtained from the aqueous extracts revealed the presence of low-molecular-weight peptides. These fractions were clearly toxic since they were lethal to crickets. Moreover, the low-molecular-weight fractions obtained from $P$. strigosa and $P$. astreoides extracts seem to be more complex and contain peptides that exert vasoconstrictor activity on isolated rat aortic rings.
The aqueous extracts of the scleractinian corals analyzed in this study induce toxicological, pharmacological and biochemical effects similar to those observed with cnidarians that are toxic to humans. For example, most of the biological activities reported in this study for these corals are also induced by the aqueous extract of the hydrozoan fire coral M. complanata. Millepora species possess two types of nematocyst capable of penetrating human skin, macrobasic mastigophores and stenoteles [57]. In the current study we observed that these scleractinian corals possess mainly holotrich and p-rhabdoid nematocysts; however, a detailed study by electron microscopy is necessary for a proper identification.

Studies on other scleractinian corals have shown that those corals present the four basic morphological patterns of cnidae found in Hexacorallia: spirocysts, holotrich, b- and p-rhabdoids [58]. These observations suggest that the fact that these corals are not considered toxic to humans may be due to a lack of nematocysts capable of penetrating human skin. It is important to mention that the method previously used for the isolation of nematocysts from Millepora species did not work with these scleractinian corals. Thus, the nematocysts were directly observed from small samples of soft tissues of the corals. This difficulty to obtain extracts of nematocysts from these corals explains the scarcity of studies on the toxicity of these organisms.

\section{Conclusions}

In summary, the results of this study show that the aqueous extracts of the scleractinian corals $P$. strigosa, $P$. astroides, and $S$. siderea are composed of cytolysins capable of lysing human and rat erythrocytes, toxins that induce nociceptive responses, and enzymes such as serine proteases and PLA $\mathrm{A}_{2}$ that undoubtedly play an important role in the toxicity of these corals. This study also has suggested that these corals contain low-molecularweight peptides that are lethal to crickets. Moreover, this study suggests that the scleractinian corals can also produce low-molecular-weight vasoconstrictor peptides. Determining the identity and action mechanism of these peptides is a very important step to pursue.

\footnotetext{
Acknowledgements

AGA, ARM, and CIA thank CONACYT-Querétaro State Government FOMIX-QRO QRO-2014-C03-250289. RAE and FLP wish to thank PAPIIT IN 202614 for financial support.

\section{Funding}

This work was supported by grant FOFI-UAQ-2015/FCQ201606 from the Universidad Autónoma de Querétaro to A. García-Arredondo.

\section{Authors' contributions}

AGA performed the bioassays and the extracts fractionation. ARM and CIA supervised the pharmacological assays. JSR made substantial contributions to the specimen collection. FLP and RAE performed the chemical analysis of the fractions. AGA designed this project, coordinated all the activities, and wrote the manuscript. All authors read and approved the final manuscript.
} 


\section{Competing interests}

The authors declare that they have no competing interests.

\section{Ethics approval and consent to participate}

The animal utilization was approved by the Committee of Bioethics of the School of Medicine, UAQ. Specimen collection was conducted according to the guidelines of the National Commission of Aquaculture and Fishing, of the Secretariat of Agriculture, Livestock, Rural Development, Fishing, and Feeding of the Mexican Federal Government (permit number PPF/DGOPA-193/13).

\section{Author details}

'Departamento de Investigación Química y Farmacológica de Productos Naturales, Facultad de Química, Universidad Autónoma de Querétaro, Querétaro 76010, Mexico. ²Departamento de Ciencias de la Salud, Universidad Autónoma Metropolitana, Campus Iztapalapa, Mexico City 09340, Mexico. Instituto de Química, Universidad Nacional Autónoma de México, Mexico City 04510, Mexico. ${ }^{4}$ Unidad Académica de Sistemas Arrecifales, Instituto de Ciencias del Mar y Limnología, Universidad Nacional Autónoma de México, Puerto Morelos, Quintana Roo 77500, Mexico.

\section{Received: 8 August 2016 Accepted: 12 November 2016}

\section{Published online: 24 November 2016}

\section{References}

1. Folino-Rorem NC. Phylum Cnidaria. In: Thorp JH, Rogers DC, editors. Throp and Covich's freshwater invertebrates: Ecology and general biology: Fourth Edition. Ámsterdam: Elsevier Inc.; 2015. p. 159-79.

2. Beckmann A, Özbek S. The nematocyst: a molecular map of the cnidarian stinging organelle. Int J Dev Biol. 2012;56(6-8):577-82.

3. Turk T, Kem WR. The phylum Cnidaria and investigations of its toxins and venoms until 1990. Toxicon. 2009;54(8):1031-7.

4. Jouiaei M, Yanagihara AA, Madio B, Nevalainen TJ, Alewood PF, Fry BG. Ancient venom systems: a review on cnidaria toxins. Toxins. 2015;7(6):2251-71.

5. Sher D, Zlotkin E. A hydra with many heads: protein and polypeptide toxins from hydra and their biological roles. Toxicon. 2009;54(8):1148-61.

6. García-Arredondo A, Murillo-Esquivel L, Rojas A, Sanchez-Rodriguez J. Characteristics of hemolytic activity induced by the aqueous extract of the Mexican fire coral Millepora complanata. J Venom Anim Toxins incl Trop Dis. 2014;20(1):49

7. Changyun W, Haiyan L, Changlun S, Yanan W, Liang L, Huashi G. Chemical defensive substances of soft corals and gorgonians. Acta Ecol Sin. 2008;28(5):2320-8

8. Cordie DR, Budd AF. Histological data in a combined phylogenetic analysis of scleractinian reef corals. J Morphol. 2016;277(4):494-511.

9. Gunthorpe L, Cameron AM. Widespread but variable toxicity in scleractinian corals. Toxicon. 1990;28(10):1199-219.

10. Bradford MM. A rapid and sensitive method for the quantification of microgram quantities of protein utilizing the principle of protein-dye binding. Anal Biochem. 1976;72:248-54.

11. Herzig V, Khalife AA, Chong Y, Isbister GK, Currie BJ, Churchill TB, et al. Intersexual variations in Northern (Missulena pruinosa) and Eastern (M. bradleyi) mouse spider venom. Toxicon. 2008:51(7):1167-77.

12. Torres M, Aguilar MB, Falcón A, Sánchez L, Radwan FFY, Burnett JW, et al. Electrophysiological and hemolytic activity elicited by the venom of jellyfish Cassiopea xamachana. Toxicon. 2001;39(9):1297-307.

13. García-Arredondo A, Rojas-Molina A, Bah M, Ibarra-Alvarado C, GallegosCorona MA, García-Servín M. Systemic toxic effects induced by the aqueous extract of the fire coral Millepora complanata and partial purification of thermostable neurotoxins wit lethal effects in mice. Comp Biochem Physiol C Toxicol Pharmacol. 2015;169:55-64.

14. Dubuisson D, Dennis SG. The formalin test: a quantitative study of the analgesic effects of morphine, meperidine, and brain stem stimulation in rats and cats. Pain. 1977;4(2):161-74.

15. Erlanger BF, Kokowsky N, Cohen W. The preparation and properties of two new chromogenic substrates of trypsin. Arch Biochem Biophys. 1961;95:271-8.

16. Di Ferrante N. Turbidimetric measurement of acid mucopolysaccharides and hyaluronidase activity. J Biol Chem. 1956;220(1):303-6.

17. Laemmli UK. Cleavage of structural proteins during the assembly of the head of bacteriophage T4. Nature. 1970;227(5259):680-5.

18. Tejuca M, Anderluh G, Dalla SM. Sea anemone cytolysins as toxic components of immunotoxins. Toxicon. 2009;54(8):1206-14.
19. Wei WC, Sung PJ, Duh CY, Chen BW, Sheu JH, Yang NS. Anti-inflammatory activities of natural products isolated from soft corals of Taiwan between 2008 and 2012. Mar Drugs. 2013;11(10):4083-126.

20. Mariottini GL, Pane L. Cytotoxic and cytolytic cnidarian venoms. A review on health implications and possible therapeutic applications. Toxins (Basel). 2014;6(1):108-51.

21. Mariottini GL, Grice ID. Antimicrobials from cnidarians. A new perspective for anti-infective therapy? Mar Drugs. 2016;14(3). doi:10.3390/md14030048.

22. Álvarez C, Mancheño JM, Martínez D, Tejuca M, Pazos F, Lanio ME. Sticholysins, two pore-forming toxins produced by the Caribbean Sea anemone Stichodactyla helianthus: Their interaction with membranes. Toxicon. 2009;54(8):1135-47.

23. Bosmans F, Tytgat J. Sea anemone venom as a source of insecticidal peptides acting on voltage-gated $\mathrm{Na}^{+}$channels. Toxicon. 2007:49(4):550-60.

24. Yan F, Cheng $X$, Ding $X$, Yao T, Chen H, Li W, et al. Improved insecticida toxicity by fusing Cy1Ac of Bacillus thuringiensis with Av3 of Anemonia viridis. Curr Microbiol. 2014;68(5):604-9.

25. Houlbrèque F, Ferrier-Pagès $C$. Heterotrophy in tropical scleractinian corals. Biol Rev Camb Philos Soc. 2009:84(1):1-17.

26. Rojas-Molina A, García-Arredondo A, Ibarra-Alvarado C, Bah M. Millepora ("fire corals") species: toxinological studies until 2011. In: Daniels JA, editor. Advances in environmental research, vol. 26. New York: Nova; 2012. p. 133-48.

27. García-Arredondo A, Rodriguez-Rios L, Díaz-Peña LF, Vega-Ángeles R. Pharmacological characterization of venoms from three theraphosid spiders: Poecilotheria regalis, Ceratogyrus darlingi and Brachypelma epicureanum. J Venom Anim Toxins incl Trop Dis. 2015:21:15.

28. Anderluh G, Macek P. Cytolytic peptide and protein toxins from sea anemones (Anthozoa: Actiniaria). Toxicon. 2002:40(2):111-24

29. Norton RS. Structures of sea anemone toxins. Toxicon. 2009;54(8):1075-88.

30. Rojko N, Dalla Serra M, Macek P, Anderluh G. Pore formation by actinoporins, cytolysins from sea anemones. Biochim Biophys Acta. 2016; 1858(3):446-56.

31. Kristan KC, Viero G, Dalla Serra M, Macek P, Anderluh G. Molecular mechanism of pore formation by actinoporins. Toxicon. 2009;54(8):1125-34.

32. Suput D. In vivo effects of cnidarian toxins and venoms. Toxicon. 2009; 54(8):1190-200.

33. Suput D, Frangez R, Bunc M. Cardiovascular effect of equinatoxin III from the sea anemone Actinia equina (L.). Toxicon. 2001;39(9):1421-7.

34. Loredo JS, Gonzalez Jr RR, Hessinger DA. Effect of Portuguese man-of-war venom on isolated vascular segments. J Pharmacol Exp Ther. 1986;236(1): 140-3.

35. Kim E, Lee S, Kim JS, Yoon WD, Lim D, Hart AJ, et al. Cardiovascular effects of Nemopilema nomurai (Scyphozoa: Rhizostomeae) jellyfish venom in rats. Toxicol Lett. 2006:167(3):205-11.

36. Wang B, Zhang B, Wang Q, Zhang Z, Nie F, Liu G, et al. Pharmacological studies of tentacle extract from the jellyfish Cyanea capillata in isolated rat aorta. Mar Drugs. 2013;11(9):3335-49.

37. Ibarra-Alvarado C, García JA, Aguilar MB, Rojas A, Falcón A, de la Cotera EP H. Biochemical and Pharmacological characterization of toxins obtained from the fire coral Millepora complanata. Comp Biochem Physiol8 C Toxicol Pharmacol. 2007;146(4):511-8.

38. García-Arredondo A, Rojas-Molina A, Ibarra-Alvarado C, Iglesias-Prieto R. Effects of bleaching on the pharmacological and toxicological activities elicited by the aqueous extracts prepared from two "fire corals" collected in the Mexican Caribbean. J Exp Mar Biol Ecol. 2011;396(2):171-6.

39. Burnett JW. Treatment of Atlantic cnidarian envenomations. Toxicon. 2009;54(8):1201-5.

40. Berling I, Isbister G. Marine envenomations. Aust Fam Physician. 2015;44(1):28-32.

41. Cuypers E, Yanagihara A, Karlsson E, Tytgat J. Jellyfish and other cnidarian envenomations cause pain affecting TRPV1 channels. FEBS Lett. 2006; 580(24):5728-32.

42. Andreev YA, Kozlov SA, Koshelev SG, Ivanova EA, Monastyrnaya MM, Kozlovskaya EP, et al. Analgesic compound from sea anemone Heteractis crispa is the first polypeptide inhibitor of vanilloid receptor 1 (TRPV1). J Biol Chem. 2008;283(35):23914-21.

43. Kozlov SA, Andreev YA, Murashev AN, Skobtsov DI, D'lachenko IA, Grishin EV. New polypeptide components from the Heteractis crispa sea anemone with analgesic activity. Bioorg Khim. 2009;35(6):789-98 [Article in Russian].

44. Nevalainen TJ, Peuravuori HJ, Quinn RJ, Llewellyn LE, Benzie JA, Fenner PJ, et al. Phospholipase A2 in cnidaria. Comp Biochem Physiol B Biochem Mol Biol. 2004;139(4):731-5. 
45. Kordis D. Evolution of phospholipase A2 toxins in venomous animals. Acta Chim Slov. 2011;58(4):638-46.

46. Radwan FF, Aboul-Dahab HM. Milleporin 1, a new phospholipase $A_{2}$ active protein from the fire coral Millepora platyphylla nematocysts. Comp Biochem Physiol C Toxicol Pharmacol. 2004;139(4):267-72.

47. Casewell NR, Harrison RA, Wuster W, Wagstaff SC. Comparative venom gland transcriptome surveys of the saw-scaled vipers (Viperidae: Echis) reveal substantial intra-family gene diversity and novel venom transcripts. BMC Genomics. 2009;10:564.

48. Serrano SM, Maroun RC. Snake venom serine proteinases: sequence homology vs. substrate specificity, a paradox to be solved. Toxicon. 2005;45(8):1115-32.

49. Ma Y, Zhao R, He Y, Li S, Liu J, Wu Y, et al. Transcriptome analysis of the venom gland of the scorpion Scorpiops jendeki: implication for the evolution of the scorpion venom arsenal. BMC Genom. 2009:10:290.

50. Bordon KC, Wiezel GA, Amorim FG, Arantes EC. Arthopod venom Hyaluronidases: biochemical properties and potential applications in medicine and biotechnology. J Venom Anim Toxins incl Trop Dis. 2015;21:43.

51. Gacesa R, Chung R, Dunn SR, Weston AJ, Jaimes-Becerra A, Marques AC, et al. Gene duplications are extensive and contribute significantly to the toxic proteome of nematocysts isolated from Acropora digitifera (Cnidaria: Anthozoa: Scleractinia). BMC Genom. 2015;16:774.

52. Liu G, Zhou Y, Liu D, Wang Q, Ruan Z, He Q, et al. Global transcriptome analysis of the tentacle of the jellyfish Cyanea capillata using deep sequencing and expressed sequence tags: Insight into the toxin and degenerative disease-related transcripts. PLoS One. 2015;10(11):e0142680.

53. Knottel PS, Long PF, Brammall L, Marques AC, Almeida MT, Padilla G, et al. Characterizing the enzymatic profile of crude tentacle extracts from the South Atlantic Jellyfish Olindias sambaquiensis (Cnidaria: Hydrozoa). Toxicon. 2016:119:1-7.

54. Lazcano-Pérez F, Hernández-Guzman U, Sánchez-Rodriguez J, ArreguinEspinosa R. Cnidarian neurotoxic peptides affecting central nervous system targets. Cent Nerv Syst Agents Med Chem. 2015. [Epub ahead of print]

55. Honma T, Shiomi K. Peptide toxins in sea anemones: Structural and functional aspects. Mar Biotechnol (NY). 2006;8(1):1-10.

56. Zykova TA, Monastyrnaia MM, Apalikova OV, Shvets TV, Kozlovskaia EP. Low-molecular cytolysins and trypsin inhibitors from sea anemone Radianthus macrodctylus. Isolation and partial characterization. Bioorg Khim. 1998;24(7):509-16 [Article in Russian].

57. García-Arredondo A, Rojas A, Iglesias-Prieto R, Zepeda-Rodriguez A, PalmaTirado L. Structure of nematocysts isolated from the fire corals Millepora alcicornis and Millepora complanata (Cnidaria: Hydrozoa). J Venom Anim Toxins incl Trop Dis. 2012;18(1):109-15.

58. Oliveira PD. Cnidae of Scleractinia. Proc Biol Soc Wash. 1997;110(2):167-85.

\section{Submit your next manuscript to BioMed Central and we will help you at every step:}

- We accept pre-submission inquiries

- Our selector tool helps you to find the most relevant journal

- We provide round the clock customer support

- Convenient online submission

- Thorough peer review

- Inclusion in PubMed and all major indexing services

- Maximum visibility for your research

Submit your manuscript at www.biomedcentral.com/submit

Biomed Central 